\title{
GENERATION, CHARACTERISTICS AND DISPOSAL OF SEWAGE SLUDGE PRODUCED ON TREATMENT PLANT OF TATARSTAN
}

\author{
Svetlana Yu. Selivanovskaya, \\ Venera Z. Latypova \\ Kazan State University, Russia
}

\begin{abstract}
Treatment of wastewater unavoidably results in the generation of huge quantities of sludge in which pollutants concentrate and which must be disposed of. The aim of this study was to compare the quality of organic matter, the metal composition and toxic organic content in different sewage sludge. The presence of these substances caused environmental damage in soil, plants, groundwater and air. Sewage sludge was periodically sampled from five treatment plant treated municipal and industrial wastewater in common in Almetevsk, Elabuga, Zainsk, Kazan, Chistopol (Tatarstan, Russia). Knowledge of the metal content of the sludge is a key step in selecting or in ruling out the various disposal alternatives. For the approval of possible utilization of sewage sludge as fertilizer the estimation of the chemical compounds has to be supplemented with the toxicity bioassay
\end{abstract}

\section{Introduction}

The urgency of the decision of the problem of the anthropogenic compounds accumulation in biosphere is undoubted. Pollutants can reach natural and agricultural soil and sphere contiguous to them from various sources. In Russia the Federal Legislation required both municipalities and industries to implement rigorous wastewater treatments to abate water pollution. Treatment of wastewater unavoidably results in the generation of huge quantity of sludge in which pollutants can concentrate and which must be disposed of. In the industrial countries annual amount of dry matter of sewage sludge per one inhabitant consists of 30-124 $\mathrm{g}$, namely $36-77 \mathrm{~g}$ of them are produced from mechanical treatment of wastewaters, $5-40 \mathrm{~g}$ from the biotreatment and 12-68 g under chemical treatment (Puolanne, 1984). Different reports indicated that U.S. was producing $6.2 \times 10^{6}$ West Germany, $2.2 \times 10^{6}$, U.K., $1.5 \times 10^{6}$, Italy, $1.2 \times 10^{6}$ metric tons/ year of dry sewage sludge fifteen years ago (Hue, 1995). Sludge production is expected to reach approximately $12 \times 10^{6}$ metric tons by the year 2000 . The calculated annual amount of the sewage sludge produced in Russia possessed $141 \mathrm{mln}$ inhabitants including $101 \mathrm{mln}$ of the citizens is estimated as $2.5 \times 10^{6}$ metric tons of dry matter (Rusakov et al., 1995). 


\section{Wastewater treatment process on the treatment station in Tatarstan}

Domestic and industrial discharged are probably the two major sources of sewage sludge production. In the large cities of Tatarstan (Tatarstan, Russia) the industrial enterprises are not equipped with their own wastewater treatment plants and therefore the industrial wastewaters are sewered along with the municipal.

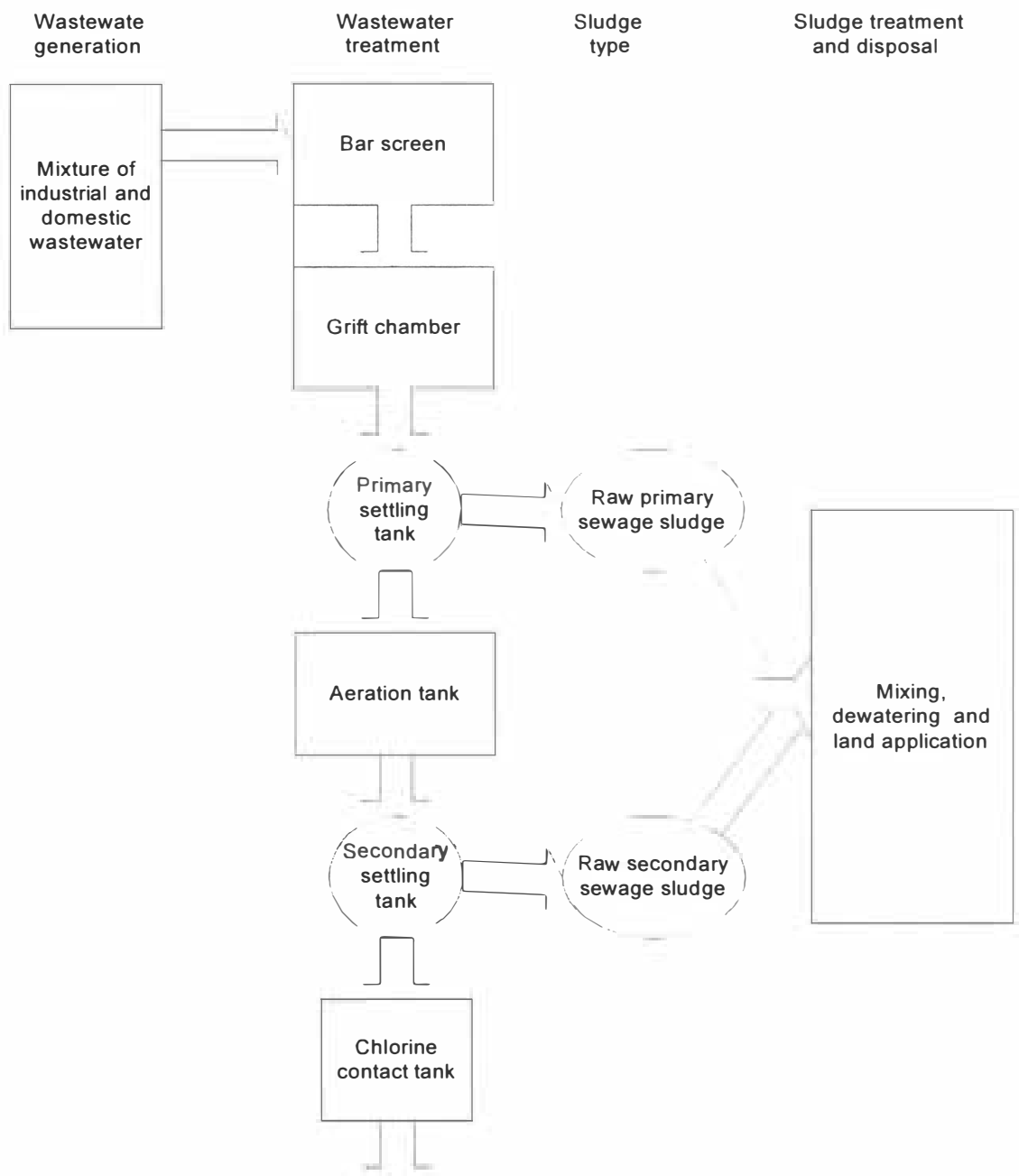

Figure 1. Common scheme of generation and disposal of municipal sewage sludge in the treatment plant of cities of Tatarstan 
In this paper the term «municipal» will be used to represent the mixture of the domestic and industrial wastewater. The most common treatment plants for municipal wastewater treatment in the large cities of Tatarstan is the activated sludge plants. The treatment units in the activated sludge plants include bar screen, grit chamber, primary settling tank, aeration tank, final settling tank, and chlorine contact tank (Fig.1). Once pumped into a wastewater treatment plant, the municipal wastewater after the bar screen and grit chamber is held in a large clarifying tank and undergoes primary treatment that removes readily settleable solids. The primary sludge produced on that stage usually contains $3-7 \%$ solids. Then the wastewater further undergoes secondary treatment, which involves activated sludge system. Secondary treatment removes fine suspended solids and some dissolved solids, and produces secondary sludge. Secondary sludge generally has $0.5-2.0 \%$ solids. Then raw sewage sludge, both primary and secondary are combined. Stabilization processes such as anaerobic

digestion and aerobic digestion are absent In some case the sewage sludge are composted. Sludge volume is reduced by partially elimination of the water. Treatment processes such as dewatering can lower sludge water content and raise the solids percentage. Dewatering is accomplished through centrifugation or filter press. But only some part of the sewage sludge produced is dewatered. The main part of it is undergoes to the land application. This succession of the treatment processes provides with the satisfactory efficiency of the effluent. For example the effluent of the treatment station of the Kazan (Russia, Tatarstan) characterized by the following average value of parameters $(\mathrm{mg} / \mathrm{l})$ : MLSVS - $16.3, \mathrm{BOD}_{5}$ 10.9, $\mathrm{COD}-90, \mathrm{~N}-\mathrm{NH}_{4}-7.4, \mathrm{~N}-\mathrm{NO}_{2}-0.26, \mathrm{~N}-\mathrm{NO}_{3}-1.49, \mathrm{P}-\mathrm{PO}_{4}-3.3$, phenol - 0.004, oil product $-0.52, \mathrm{Cl}^{-}-74, \mathrm{~F}^{-}-0.004, \mathrm{SO}^{4--}-105, \mathrm{Fe}-0.42, \mathrm{Al}-0.016, \mathrm{Cr}-0.031, \mathrm{Cu}-0.024$, $\mathrm{Zn}-0.006, \mathrm{Ni}-0.005, \mathrm{Cd}-\mathrm{ND}$. However, the prolonged storage of the sewage sludge during the land application may caused the impact effect of its compounds on the environment.

\section{Sludge characteristic}

Municipal sewage sludge contains various amounts of industrial wastes in addition to human excreta and residuals from household activities. So, the main groups of sludge constituents controlling or limiting the use or disposal options of sludge are nutrients, metals, toxic organic chemicals. During the period of 1991-1999 year the monitoring of the sludge content were performed. The sewage sludge of five largest cities of Tatarstan (Almetevsk, Elabuga, Zainsk, Kazan, Chistopol) were examined. Data, presented in Table 1 show the high content of the organogenic elements represented the major nutrient cycles of the earth. The average content of the organic matter in sewage sludge varies from 3 to $25 \%$. 
Table 1

Concentration of selected plant nutrients in sewage sludge of five cities of Tatarstan

\begin{tabular}{|l|l|l|l|l|l|}
\hline \multirow{2}{*}{ Parameters } & Nutrients & \multicolumn{5}{l|}{} \\
\cline { 2 - 6 } & Almetevsk & Elabuga & Zainsk & Kazan & Chistopol \\
\hline Corg,\% & 8.28 & 23.96 & 11.69 & 25.02 & 13.42 \\
\hline $\mathrm{N}_{\text {total } \%} \%$ & 0.39 & 1.65 & 0.79 & 1.86 & 2.56 \\
\hline $\mathrm{N}\left(\mathrm{NH}_{4}\right), \%$ & 0.004 & 0.0055 & 0.01 & 0.0045 & 0.045 \\
\hline $\mathrm{N}\left(\mathrm{NO}_{3}\right), \mathrm{mg} / \mathrm{kg}$ & 8.37 & 28.3 & 19.1 & 34.77 & 61.5 \\
\hline $\mathrm{P}_{\text {total } \%} \%$ & 0.38 & 0.25 & 0.75 & 0.49 & 0.38 \\
\hline $\begin{array}{l}\mathrm{P} \text { extractable., } \\
\mathrm{mg} / 100 \mathrm{~g}\end{array}$ & 60.9 & 120.2 & 99.56 & 29.74 & 57.9 \\
\hline $\mathrm{K}_{\text {total, \% }}$ extractable, & 1.78 & 1.59 & 0.49 & 2.1 & 1.94 \\
\hline $\begin{array}{l}\mathrm{mg} / 100 \mathrm{~g} \\
\mathrm{mg}\end{array}$ & 47.06 & 47.3 & 34.8 & 30.1 \\
\hline $\mathrm{By}$ & & & & \\
\hline
\end{tabular}

By average median concentrations from all five sludge listed in Table 1 sewage sludge, produced on treatment station of Tatarstan would contain $1.45 \% \mathrm{~N}, 0.45 \% \mathrm{P}, 1.57 \% \mathrm{~K}$. These nutrients value are similar to those in animal manure. For this reason sludge may be applied to agricultural land, forest land and disturbed land as fertilizer, soil conditioner or as soil regeneration agent.

However the sewage sludge may be enriched by heavy metals contents. Some of these elements (e.g. $\mathrm{Cu}$ and $\mathrm{Zn}$ ) are essential to plants and animals in small amounts, but become toxic in excess. Moreover the toxic metals cannot be removed from the soil, as become irreversibly immobilized within different soil components (humified organic matter, Fe and $\mathrm{Al}$ oxides and hydroxides, clay particles etc.). There can result in the long-term effects of these elements at high concentrations in the environment as they can persist in the soil for hundreds years. Concentration of heavy metals in sludge are among the deciding factors for sludge utilization on lands because of their potential to damage crops to enter the human food chain. The performance of heavy metals existed in the sludge depends on the origin of the sludge. Table 2 depicts the distribution of heavy metals among the sludge produced in the different treatment station of Tatarstan. Concentration of sludge metals vary widely. For examples, Cd levels range from 1 to $65.7, \mathrm{Zn}$ - from57.8 to $20500, \mathrm{~Pb}$ - from 23.8 to $305, \mathrm{Cu}$ from 57.8 to $3114, \mathrm{Cr}$ - from 150 to $7440 \mathrm{Ni}$ - from 44 to $1306, \mathrm{Hg}$ - from 0.01 to $0.9 \mathrm{mg} / \mathrm{kg}$. Despite these large variations, median concentrations of the metals are relatively low. It is very important especially to take notice of the cadmium content because it can accumulate in plants up to levels toxic to humans and animals but which are below the levels that are toxic to the plants.

Industrial wastes, household chemicals, and pesticides are main contributors to organic chemicals in sludge. These chemicals are of concern because of their known and unknown hazards to the public health and environment. In some cases 
Table 2

Total concentration of selected metals in sewage sludge of treatment station of Tatarstan cities (mg/kg dry weight)

\begin{tabular}{|c|c|c|c|c|c|}
\hline Parameter & $\begin{array}{l}\text { Almetevsk } \\
\text { Range } \\
\text { Median }\end{array}$ & Elabuga & Zainsk & Kazan & Chistipol \\
\hline $\mathrm{Zn}$ & $\underline{57.8-434.8}$ & $1450-1+460$ & $\underline{580-20500}$ & $1150-2600$ & 1846-3412 \\
\hline & 536 & 1453 & 1228 & 1656 & 2302 \\
\hline $\mathrm{Pb}$ & $\frac{23.8-85_{2} 5}{44}$ & $\frac{86-88}{86}$ & $\frac{84-144}{119}$ & $\frac{120-200}{131}$ & $\frac{130-305}{234}$ \\
\hline $\mathrm{Cd}$ & $\frac{4.0-65.7}{36}$ & $\frac{1.6-1.7}{1}$ & $\frac{1.0-28.3}{7}$ & $\frac{50-62}{17}$ & $\frac{10-32}{19}$ \\
\hline $\mathrm{Cu}$ & $\frac{57.8-434.8}{21 d}$ & $\frac{140-143}{141}$ & $\frac{126-259}{213}$ & $\frac{700-1600}{850}$ & $\frac{1908-3114}{2594}$ \\
\hline $\mathrm{Cr}$ & $\frac{163.5-458.5}{297}$ & $\frac{1040-1050}{1043}$ & $\frac{150-1760}{985}$ & $\frac{3400-7470}{1940}$ & $\frac{930-4740}{2558}$ \\
\hline $\mathrm{Ni}$ & $\frac{47.1-123.9}{90}$ & $\frac{44-46}{45}$ & $\frac{52-95}{63}$ & $\frac{280-1 \notin 00}{1280}$ & $\frac{598-1806}{1078}$ \\
\hline $\mathrm{Mn}$ & $\frac{39 \text { de } 2-580.0}{496}$ & $\frac{162-164}{163}$ & $\frac{370-680}{554}$ & $\frac{350-500}{400}$ & $\frac{887-2412}{1305}$ \\
\hline Co & $\frac{8-24}{14}$ & $\frac{12-14}{13}$ & $\frac{7-15}{10}$ & $\frac{8-21}{12}$ & $\frac{10-28}{19}$ \\
\hline Mo & $\frac{0.2-0.3}{11}$ & $\frac{0.1 \mathrm{e} 0.18}{0,2}$ & $\frac{0.1 \mathrm{e} 0.24}{1,17}$ & $\frac{0.1-0.22}{0,12}$ & $\frac{12-52}{31}$ \\
\hline $\mathrm{Hg}$ & $\frac{0.01 \mathrm{e} 0.29}{0,09}$ & $\frac{0.8-0.9}{0,83}$ & $\frac{0.004-0.05}{0,03}$ & $\begin{array}{l}0.29-0.44 \\
0,28\end{array}$ & $\frac{0.24-0.53}{0,37}$ \\
\hline
\end{tabular}

the sludge is contaminated with benz(a)pyrene, polychlorinated biphenyl and other toxic organics. The presence of these compounds is more characteristic to the sludge formed in the simultaneous treatment of the municipal wastewater and the wastewater of the petrochemical industry but it can observed in the municipal sludges too (table.3). Thus, the sewage sludge produced in the municipal treatment plants is often enriched by heavy metals and toxic organics. The presence of these substances can cause environmental damage in soil, plants and groundwater.

The large quantity of sludge produced in Tatarstan must be moved out of wastewater treatment plants for disposal or preferably for beneficial use. The alternatives of traditional disposal include thermal treament (incineration), land application and ocean dumping. All of these being objectionable to some extent because of major problems created by the pollutants in the sludge. Land application is generally both an inexpensive and attractive way of disposal. The use of sludge in agriculture and forestry as partial substitute of fertilizers and as amendment for physical properties of soil for its restoration is a common practice. At present Regulation fixing the composition of sewage sludge intended for agricultural application is established in Russia (table 4). 
Table 3

Concentration of the selected toxic organic chemicals in sewage sludge of Tatarstan cities

\begin{tabular}{|l|l|l|l|l|l|}
\hline Parameters & Almetevsk & Elabuga & Zainsk & Kazan & $\begin{array}{l}\text { Chistopo } \\
1\end{array}$ \\
\hline $\begin{array}{l}\text { Benzo(a)pyrene, } \\
\mu \mathrm{g} / \mathrm{kg}\end{array}$ & $27-280$ & $13-19$ & $9,0-18,5$ & $120-160$ & $8,7-18,5$ \\
\hline $\begin{array}{l}\mathrm{DDT} \text { and its } \\
\mathrm{metabolites,} \\
\mathrm{mg} / \mathrm{kg}\end{array}$ & $0,001-0,011$ & 0,001 & $<0,001$ & $\begin{array}{l}<0,005- \\
0,265\end{array}$ & $\begin{array}{l}<0,005- \\
0,059\end{array}$ \\
\hline $\mathrm{PCB}, \mathrm{mg} / \mathrm{kg}$ & - & - & $<0,002$ & $<0,005$ & $<0,005$ \\
\hline $\begin{array}{l}\text { Lindan, mg/kg } \\
\text { Oil products, }\end{array}$ & - & - & $<0,002$ & $<0,003-0,1$ & $\begin{array}{l}<0,005- \\
0,034\end{array}$ \\
\hline $\begin{array}{l}\text { O/kg } \\
\mathrm{g} / \mathrm{kg}-1,8\end{array}$ & $2,4-2,5$ & $0,18-0,46$ & $1,23-10,65$ & $\begin{array}{l}0,358- \\
2,17\end{array}$ \\
\hline $\begin{array}{l}\text { Phenols flying, } \\
\mathrm{mg} / \mathrm{kg}\end{array}$ & $0,05-1,2$ & $0,05-0,08$ & $0,04-0,08$ & $0,05-0,1$ & $\begin{array}{l}2,8- \\
14,06\end{array}$ \\
\hline
\end{tabular}

Established limit values for metals in sludge are identical to those recommended by the EEC and USA in most cases except for Mn (Novelle der Klasschlammverordnung, 1993, GarciaDelgado et al.,1994, Tsadilas, 1995, Soler-Rovira, 1996, Hani, 1996). The maximum admissible concentration of $\mathrm{Mn}$ in the sludge established in Russia is higher than that in European countries. Thus, the algorythm of the adoption of the decision about the suitability of the sewage sludge for agricultural use is based on the chemical analysis followed by the comparison with Regulation mentioned above. However in our opinion final conclusion has to take into

\section{Table 4}

Standards for sewage sludge for agricultural application in different countries

\begin{tabular}{|c|c|c|c|c|c|}
\hline \multirow[t]{3}{*}{ Parameters } & \multicolumn{5}{|c|}{ Limit values, $\mathrm{mg} / \mathrm{kg}$} \\
\hline & \multirow{2}{*}{$\begin{array}{l}\text { Limits } \\
\text { European } \\
\text { countries }\end{array}$} & \multicolumn{2}{|c|}{ EEC limits } & \multirow[t]{2}{*}{ USA limits } & \multirow[t]{2}{*}{ Russia limits } \\
\hline & & $\mathrm{pH}<7$ & $\mathrm{pH}>7$ & & \\
\hline Arsenic & $10-100$ & & & & 20 \\
\hline Mercury & $6-10$ & 16 & 25 & & 15 \\
\hline Lead & $300-900$ & 750 & 1200 & 500 & 1000 \\
\hline Cadmium & $8-15$ & 20 & 40 & 50 & 30 \\
\hline Nickel & $26-500$ & 300 & 400 & 150 & 400 \\
\hline Chrome & $40-1000$ & 1000 & 1500 & 500 & 1200 \\
\hline Manganese & 500 & & & & 2000 \\
\hline Zinc & $2000-10000$ & 2500 & 4000 & 1500 & 4000 \\
\hline Copper & $300-3000$ & 1000 & 1750 & 750 & 1500 \\
\hline
\end{tabular}

account the possible presence of unforeseen toxic organics in the sludge. These compounds can be produced in chemical reaction between the initial components or can be intermediates of microbial metabolism. It is known that these compounds are often proved to be more toxic than the compounds mentioned in Regulation. Moreover they can possess the genotoxicity. 
Based on this, the chemical analysis must be supplemented by i) bioassay of the toxicity by means of the test objects organised differently, ii) determination of the genotoxicity of the sewage sludge. Although the bioassay does not indicate the nature of toxic agents it informs the effiect of the discharge of the sludge on the biota in soil. Thus, the analysis of the literature and experimental data indicates that the sludges in spite of valuable agrochemical properties can contain the heavy metals and the toxic organics. This is testified to the urgency of the careful estimation of chemical compounds supplemented with the integral toxicity bioassay for the approval of possible utilization of sewage sludge as fertilizers.

\section{Literature}

1. Garsia-Delgado, R.A., Garsia-Herruzo, F., Gomez-Lahoz, C., Rodrigez-Maroto, J.M. (1994). Heavy metals and disposal alternatives for an anaerobic sewage sludge. J.Environ. Sci. Health. A29, pp. 1335-1347. DOI: https://doi.org/10.1080/10934529409376114

2. Hani H., Siegenthaler A., Candinas T. (1996) Soil effect due to sewage sludge application in agriculture. Fertilizer and Environment, C.Rodriguez-Barrueco (ed.), pp.267-274.

3. Hue N.V.(1995) Sewage Sludge. In Soil Ammendments and Environmemtal Quality. Jack E. Rechcigl (ed.). Lewis Publ., Boca Raton, FL, Chapter 6, pp. 199-247

4. Novelle der Klasschlammverordnung (1993) Umwelt., V.23, N4, 166p.

5. Puolanne J. (1984) Sludge production rates. In: Process. and Use Sewage Sludge. 3 Int. Symp., Brington, Sept. 27-30, 1983. Dordrecht e.a. pp.39-50.

6. Rusakov N.V., Myerzlaya G.E., Afanazev R.A., Romanenko N.A., Novosilcev G.I. (1995) Utilization of the sewage sludge in agriculture: ecological and sanitary conditions. Hygiene and Sanitation, V 4, pp. 6-10.

7. Selivanovskaya S.Yu., Latypova V.Z., Naumova R.P., Ravzieva G.M. (1997). On the possibility of involvrment of microelements of sewage sludge into biochemical circulation // Environ. Radioecology and Appl. Ecology.N1.pp.13-19.

8. Tsadilas C.D., Matsi T., Barbayiannis N., Dimoyiannis D. (1995) Influence of seawage sludge application on soil properties and on the distribution and availability of heavy metal fractions. Commun. Soil Sci. Anal., V.26,N15-16, pp. 2603-2619. DOI: https://doi.org/10.1080/00103629509369471

9. Soler-Rovira P., Soler-Soler J., Soler-Rovira J., Polo A (1996) Agricultural use of sewage sludge and its regulation. Fertilizer Research., 43, pp.173-177. 